\title{
Cardiovascular evaluation using exercise testing performed with face masks during the COVID-19 pandemic
}

\author{
Evaluación cardiovascular mediante el uso de pruebas de ejercicio, realizadas con el uso \\ de tapabocas, durante la pandemia por COVID-19
}

\author{
Hermes Ilarraza-Lomeli ${ }^{1,2 *}$, Jessica Rojano-Castillo ${ }^{1,2}$, Gonzalo Carazo ${ }^{1}$, Saray Flores ${ }^{1}$, \\ Carlos Barrera-Ramírez³, María D. Rius-Suárez ${ }^{1,2}$, and Hannah Ortega-Aranda ${ }^{1}$ \\ ${ }^{1}$ Cardiac Rehabilitation and Physical Medicine Service, Instituto Nacional de Cardiología Ignacio Chávez, Mexico City; ${ }^{2}$ Yestli Comprehensive \\ Cardiology Unit, Mexico City; ${ }^{3}$ Department of Cardiology, Hospital Universitario de Saltillo, Saltillo, Coahuila, Mexico
}

\begin{abstract}
Objective: COVID-19 pandemic is associated with high incidence and fatality, however, non-communicable diseases remain a global public health problem with even greater morbidity and mortality. At present, there is a lag in diagnosis and treatment of patients with heart disease, particularly the performance of exercise testing (ET), due to the fear of aerosol generation and viral dissemination. Although some centers carry out the tests with the use of masks, the information is still superficial and preliminary. The objective of the study was to describe the ergometric performance observed when performing exercise tests during the COVID-19 (PANDEMIC-G) pandemic and to highlight the differences with those results carried out in another time, when there was no COVID-19 (NO PANDEMIC). Method: A cross-sectional study was carried out. PANDEMIC-G patients underwent ET between March 2020 and December 2020, once a biological triage was done and all of them wore N95 masks. They were compared to NO PANDEMIC patients that performed an ET between March 2019 and December 2019. Demographic and ergometric variables were presented and analyzed according to their type. All $p<0.05$ were considered stochastically significant. Results: A total of 361 ET were studied: 209 (58\%) belonged to NO PANDEMIC and 152 (42\%) to PANDEMIC-G. The number of ET stopped by dyspnea was greater in PANDEMIC-G (117) than in NO PANDEMIC (8). Exercise tolerance did not show significant changes. Systolic blood pressure, double product, and myocardial oxygen utilization were higher in PANDEMIC-G ET $(p<0.01)$. Conclusions: In the COVID-era, fewer stress tests were performed, which were suspended more frequently due to dyspnea. Higher values of systolic blood pressure and myocardial oxygen utilization were observed in PANDEMIC-G as well.
\end{abstract}

Key words: COVID. Exercise testing. Blood pressure. Mask. Exercise tolerance. Diagnostic test.

\section{Resumen}

Objetivo: La pandemia de COVID-19 se asocia con una alta incidencia y letalidad; sin embargo, las enfermedades no transmisibles siguen siendo un problema de salud pública mundial con una morbilidad y mortalidad aún mayores. Actualmente, existe un retraso en el diagnóstico y tratamiento de los pacientes con enfermedades cardíacas, particularmente en la realización de la prueba de esfuerzo (PE), debido al temor a la generación de aerosoles y la diseminación viral. Aunque algunos

Correspondence:

*Hermes Ilarraza-Lomelí

E-mail: hermes_ilarraza@yahoo.com
Available online: $16-12-2021$ Arch Cardiol Mex. 2021;91(Supl):12-17 www.archivoscardiologia.com 1405-9940 / @ 2020 Instituto Nacional de Cardiología Ignacio Chávez. Published by Permanyer. This is an open access article under the CC BY-NC-ND license (http://creativecommons.org/licenses/by-nc-nd/4.0/). 
centros realizan las pruebas con el uso de tapabocas, la información aún es superficial y preliminar. El objetivo del estudio fue describir el desempeño ergométrico observado al realizar pruebas de ejercicio durante la pandemia COVID-19 (PANDEMIC-G) y remarcar las diferencias con las pruebas realizadas antes de ella (NO PANDEMIC). Método: Se realizó un estudio transversal. Los pacientes con PANDEMIC-G se sometieron a PE entre marzo y diciembre de 2020, una vez que se realizó un triaje biológico y todos usaron tapabocas N95. Fueron comparados con pacientes NO PANDEMIC, que realizaron una PE entre marzo y diciembre de 2019. Las variables se presentaron y analizaron según su tipo. Todos los valores de $p$ inferiores a 0.05 se consideraron estocásticamente significativos. Resultados: Se estudiaron un total de 361 PE, donde 209 (58\%) pertenecían a NO PANDEMIC y 152 (42\%) a PANDEMIC-G. El número de PE detenidas por disnea fue mayor en PANDEMIC-G $(n=117)$ que en NO PANDEMIC $(n=8)$. La tolerancia al ejercicio no mostró cambios significativos. La presión arterial sistólica, el producto doble y la utilización de oxígeno del miocardio fueron mayores en las PE en el PANDEMIC-G ( $p<0.01)$. Conclusiones: En la era COVID se realizaron menos pruebas de esfuerzo, que se suspendieron con mayor frecuencia por disnea. También se observaron valores más altos de presión arterial sistólica y utilización de oxígeno del miocardio en PANDEMIC-G.

Palabras clave: COVID. Prueba de esfuerzo. Presión arterial. Mascarilla. Tolerancia al ejercicio. Prueba diagnóstica.

The COVID-19 pandemic has hit the world in 2020, caused by the spread of SARS-COV-2, which at the end of December was associated with more than 80 million sick people and unfortunately 1.8 million deaths ${ }^{1}$. Despite this terrible problem, non-communicable diseases continue to claim more than 40 million lives worldwide, particularly those of cardiovascular origin with 18 million?

At present, there is a lag in the care of patients with heart disease, both in diagnostic and therapeutic procedures, due to this pandemic ${ }^{3}$. In particular, exercise testing (ET) has been underused or even prohibited, due to the fear of aerosol production by patient's breathing, leaving physicians without a traditional tool with great diagnostic and prognostic power ${ }^{4,5}$.

Thus, staff in cardiology centers that perform ET, ask patients to wear a mask, although its consequences are hardly being studied ${ }^{6,7}$. Nevertheless, to date, there is only partial and preliminary information on the effect of the use of these masks on the ergometric performance of an individual.

The objective of the study was to describe the ergometric performance observed when performing exercise tests during the COVID-19 (PANDEMIC-G) pandemic and to highlight the differences with the tests performed before it (NO PANDEMIC).

\section{Methods}

A cross-sectional study was carried out. Thus, we have described the patient referrals and ET performed in the "real world" during the COVID-19 pandemic (PANDEMIC-G, March-December 2020), and we have remarked the differences with the usual work performed in the same period, before the pandemic (NO PANDEMIC group).

The independent variable was the presence of the COVID-19 pandemic, with characteristics such as several epidemiological restrictions and the mandatory use of masks.

Each patient from PANDEMIC-G underwent a biological triage composed of a questionnaire looking to detect COVID symptoms, body temperature measurement, heart rate, and digital oximetry. All patients of PANDEMIC-G wore N95 masks throughout the ET and staff surveyed its proper use, ensuring that mask partially collapsed during patient inspiration. Beyond that, all exercise tests were symptom limited and carried out in a similar way as reported elsewhere ${ }^{8}$.

Variables are presented as frequency (percentage), mean (standard deviation), or median (interquartile interval) according to their type and distribution. Differences were studied using the Chi-square test, the Student's t-test for independent variables, or the Wilcoxon rank test, as appropriate. All $p<0.05$ were considered stochastically significant.

\section{Results}

A total of 361 stress tests were studied, 209 (58\%) belonging to NO PANDEMIC group and $152(42 \%)$ to PANDEMIC-G, showing a decrease of $27 \%$ in 2020 compared to 2019. Demographic variables are shown in table 1. The indications for the exercise test were as follows: risk stratification in patients with cardiovascular disease or pre-participation sports evaluation in athletes. All tests were limited by symptoms and patients with heart disease performed a modified Balke ramp protocol, while athletes underwent a Bruce ramp test. 
Table 1. Demographics

\begin{tabular}{|c|c|c|c|c|}
\hline n (\%), mean (SD) & All & No pandemic & Pandemic-G & p value \\
\hline Subjects & $361(100 \%)$ & $209(58 \%)$ & $152(42 \%)$ & $<0.05$ \\
\hline Gender & $\begin{array}{c}\mathrm{F}(67,19 \%), \mathrm{M} \\
(294,81 \%)\end{array}$ & $F(47,22 \%), M(162,78 \%)$ & $\mathrm{F}(20,19 \%), \mathrm{M}(132,81 \%)$ & $<0.05$ \\
\hline Age (y) & $46.8 \pm 20$ & $48 \pm 20$ & $45 \pm 21$ & ns \\
\hline Weight (kg) & $70.6 \pm 15$ & $70 \pm 17$ & $72 \pm 14$ & ns \\
\hline Height (cm) & $165 \pm 13$ & $164 \pm 14$ & $167 \pm 11$ & ns \\
\hline BMI & $25.6 \pm 5$ & $25.5 \pm 5$ & $25.8 \pm 5$ & ns \\
\hline $\begin{array}{l}\text { Diagnosis } \\
\text { IHD } \\
\text { Athl } \\
\text { CHD } \\
\text { VHD } \\
\text { Other } \\
\text { Smoking } \\
\text { Diabetes } \\
\text { Hypertension } \\
\text { Dyslipidemia } \\
\text { Beta-blocker } \\
\text { ACEi/ATIli } \\
\text { Digoxin } \\
\text { Calcium channel blockers } \\
\text { Statins } \\
\text { Diuretics } \\
\text { Aspirin } \\
\text { LVEF } \\
\text { SPAP }\end{array}$ & $\begin{array}{c}221(61 \%) \\
81(22 \%) \\
38(11 \%) \\
6(2 \%) \\
15(4 \%) \\
101(28 \%) \\
69(19 \%) \\
134(37 \%) \\
230(64 \%) \\
223(65 \%) \\
232(67 \%) \\
4(1.3 \%) \\
26(9 \%) \\
224(64 \%) \\
136(38 \%) \\
223(65 \%) \\
53(12) \\
33(12)\end{array}$ & $\begin{array}{c}136(65 \%) \\
29(14 \%) \\
26(12 \%) \\
4(2 \%) \\
14(7 \%) \\
62(30 \%) \\
41(20 \%) \\
80(38 \%) \\
143(65 \%) \\
145(73 \%) \\
147(75 \%) \\
2(1.2 \%) \\
15(9 \%) \\
141(70 \%) \\
91(43 \%) \\
140(70 \%) \\
52(13) \\
36(14)\end{array}$ & $\begin{array}{c}85(56 \%) \\
52(34 \%) \\
12(8 \%) \\
2(1 \%) \\
1(1 \%) \\
39(26 \%) \\
28(18 \%) \\
54(36 \%) \\
87(57 \%) \\
78(53 \%) \\
85(58 \%) \\
2(1.5 \%) \\
11(8 \%) \\
83(56 \%) \\
45(30 \%) \\
83(56 \%) \\
55(10) \\
29(8)\end{array}$ & $\begin{array}{c}\mathrm{ns} \\
<0.01 \\
\mathrm{~ns} \\
\mathrm{~ns} \\
<0.05 \\
\mathrm{~ns} \\
\mathrm{~ns} \\
\mathrm{~ns} \\
<0.05 \\
<0.01 \\
<0.01 \\
\mathrm{~ns} \\
\mathrm{~ns} \\
<0.01 \\
<0.01 \\
<0.05 \\
<0.05 \\
<0.05\end{array}$ \\
\hline
\end{tabular}

F: female; M: male; BMI: body max index; IHD: ischemic heart disease; Athl: athletic evaluation; CHD: congenital heart disease; VHD: valvular heart disease; ACEi/ATIli: angiotensin-converting enzyme and angiotensin II receptor inhibitors; LVEF: left ventricle ejection fraction; SPAP: systolic pulmonary arterial pressure.

For all subjects, the most common reasons to stop exercise test were fatigue $(n=165,43 \%)$ and dyspnea $(\mathrm{n}=125,35 \%)$. However, the ratio between dyspnea and fatigue was different between groups, where $117(77 \%)$ tests were suspended due to dyspnea in in PANDEMIC-G versus $8(4 \%)$ in NO PANDEMIC group, with an $\mathrm{OR}=6.3(95 \% \mathrm{Cl}, 4.6-8.6, \mathrm{p}<0.001$ analogously), ET suspension due to muscular fatigue was $88 \%$ $(n=178)$ in NO PANDEMIC and $16 \%(n=24)$ in PANDEMIC-G, $p<0.001$. Other less common causes of suspension were claudication ( $n=12,3 \%$ ), exercise-related hypotension $(n=8,2 \%)$, and ventricular tachycardia $(n=12,3 \%)$, among others. No mayor adverse outcome occurred.

Table 2 shows the comparison of the ergometric behavior between the individuals of both groups. Heart rate behavior, including baseline resting, maximum effort, and recovery phases, did not show significant changes between groups. However, the percentage of the maximum heart rate calculated for age was significantly lower for patients in PANDEMIC-G ( $78 \pm 12 \%$ vs. $81 \pm 14 \%, p<0.05)$, and the chronotropic index was also diminished $(6.8 \pm 2$ vs. $7.5 \pm 3$ bpm/MET, $p<0.05$ ).

The most evident ergometric differences were observed in the systemic blood pressure behavior. Along every phase of ET, systolic blood pressure showed statistically higher values for PANDEMIC-G compared to the NO PANDEMIC (Fig. 1). Exertional blood pressure index was also higher in PANDEMIC-G than NO PANDEMIC $(1.31 \pm 0.24$ vs. $1.26 \pm 0.2, p<0.05)$. Likewise, the double product and myocardial oxygen uptake in the patients of PANDEMIC-G were higher compared to the NO PANDEMIC group.

The maximum exercise tolerance did not show significant differences between groups ( $p=n s)$ and the maximal effort oxygen pulse was statistically higher in PANDEMIC-G $(17.3 \pm 6$ vs. $15.7 \pm 6, p<0.05)$. The Veterans score performed better in the NO PANDEMIC group than in PANDEMIC-G $(5.2 \pm 7$ vs. $7.1 \pm 6, p<0.05)$. 
Table 2. Comparison of the ergometric performance between no pandemic and Pandemic-G patients. This table shows patients performance at rest and exercise. No statistical differences were observed in maximal exercise tolerance, but systolic blood pressure was stochastically higher in patients that wore mask

\begin{tabular}{|c|c|c|c|c|}
\hline $\begin{array}{l}\text { Variables } \\
\text { n (\%), mean (SD) }\end{array}$ & All & No pandemic & Pandemic-G & p value \\
\hline Subjects & $361(100 \%)$ & $209(58 \%)$ & $152(42 \%)$ & \\
\hline Rest HR (bpm) & $72 \pm 15$ & $72 \pm 15$ & $73 \pm 15$ & ns \\
\hline Rest SBP (mmHg) & $108 \pm 16$ & $107 \pm 17$ & $111 \pm 15$ & $<0.01$ \\
\hline Rest DBP $(\mathrm{mmHg})$ & $71 \pm 11$ & $69 \pm 9$ & $72 \pm 12$ & $<0.05$ \\
\hline Rest DP (mmHg*bpm"1000) & $7.8 \pm 1.9$ & $7.6 \pm 1.9$ & $8.1 \pm 1.9$ & $<0.05$ \\
\hline Max HR (bpm) & $136 \pm 31$ & $136 \pm 29$ & $137 \pm 33$ & ns \\
\hline Max SBP (mmHg) & $138 \pm 27$ & $133 \pm 27$ & $145 \pm 27$ & $<0.001$ \\
\hline Max DBP $(\mathrm{mmHg})$ & $78 \pm 10$ & $77 \pm 11$ & $78 \pm 10$ & ns \\
\hline Max DP (mmHg*bpm*1000) & $19.3 \pm 7$ & $18.5 \pm 6.5$ & $20.4 \pm 7.9$ & $<0.05$ \\
\hline Recov1-HR (bpm) & $119 \pm 27$ & $119 \pm 26$ & $120 \pm 28$ & ns \\
\hline Recov1-SBP (mmHg) & $133 \pm 24$ & $128 \pm 25$ & $139 \pm 21$ & $<0.001$ \\
\hline Recov1-DBP (mmHg) & $76 \pm 10$ & $75 \pm 10$ & $76 \pm 10$ & ns \\
\hline Ischemia (n, \%) & $19(5.3)$ & $18(8.6)$ & $1(0.7)$ & \\
\hline ST changes (mm) & $(-1.3) \pm 0.5$ & $(-1) \pm 4$ & $(-1.4) \pm 5$ & ns \\
\hline Arrhythmia & $172(48 \%)$ & $100(48 \%)$ & $72(47 \%)$ & ns \\
\hline Frequent premature ventricular complexes & $37(10 \%)$ & $27(13 \%)$ & $10(6 \%)$ & $<0.05$ \\
\hline Atrial fibrillation & $5(1.4 \%)$ & $3(1.4 \%)$ & $2(1.3 \%)$ & ns \\
\hline Ventricular tachycardia & $14(3.9 \%)$ & $11(5.3 \%)$ & $3(2 \%)$ & ns \\
\hline Veteran score & $(-6) \pm 7$ & $5.2 \pm 7$ & $7.1 \pm 6$ & $<0.05$ \\
\hline Duke score & $8 \pm 5$ & $7.9 \pm 4$ & $8.5 \pm 5.3$ & ns \\
\hline Max HR (reached \%) & $79 \pm 14$ & $81 \pm 14$ & $78 \pm 12$ & $<0.05$ \\
\hline METs-Max & $9.4 \pm 4$ & $9.2 \pm 4$ & $9.6 \pm 4$ & ns \\
\hline Reached V02max (\%) & $97 \pm 34$ & $99 \pm 37$ & $93 \pm 28$ & ns \\
\hline MV02 max (ml02/100g) & $20.7 \pm 10$ & $19.6 \pm 9$ & $22.2 \pm 11$ & $<0.05$ \\
\hline Max. oxygen pulse & $16.4 \pm 6$ & $15.7 \pm 6$ & $17.3 \pm 6$ & $<0.05$ \\
\hline Pressure response (mmHg/MET) & $3 \pm 2$ & $2.8 \pm 2.1$ & $3.2 \pm 1.9$ & ns \\
\hline ESPI & $1.3 \pm 0.23$ & $1.26 \pm 0.2$ & $1.31 \pm 0.24$ & $<0.05$ \\
\hline RSPI & $0.97 \pm 0.09$ & $0.97 \pm 0.08$ & $0.97 \pm 0.11$ & ns \\
\hline $\mathrm{Cl}$ (bpm/MET) & $7.2 \pm 3$ & $7.5 \pm 3$ & $6.8 \pm 2$ & $<0.05$ \\
\hline RHR (bpm) & $64 \pm 27$ & $64 \pm 26$ & $64 \pm 27$ & ns \\
\hline HRR1(bpm) & $17 \pm 11$ & $17 \pm 11$ & $17 \pm 10$ & ns \\
\hline $\mathrm{ECP}\left({ }^{*} 1000\right)$ & $13.7 \pm 6$ & $13.5 \pm 7$ & $13.8 \pm 6$ & ns \\
\hline
\end{tabular}

HR: heart rate; SBP: systolic blood pressure; DP: double product; V02max: maximal oxygen uptake; MV02max: maximal myocardial oxygen uptake; ESPI: exertional systolic pressure index; RSPI: recovery systolic pressure index; Cl: chronotropic index; RHR: reserve heart rate; HRR1: heart rate recovery 1st min; ECP: exercise cardiac power. 


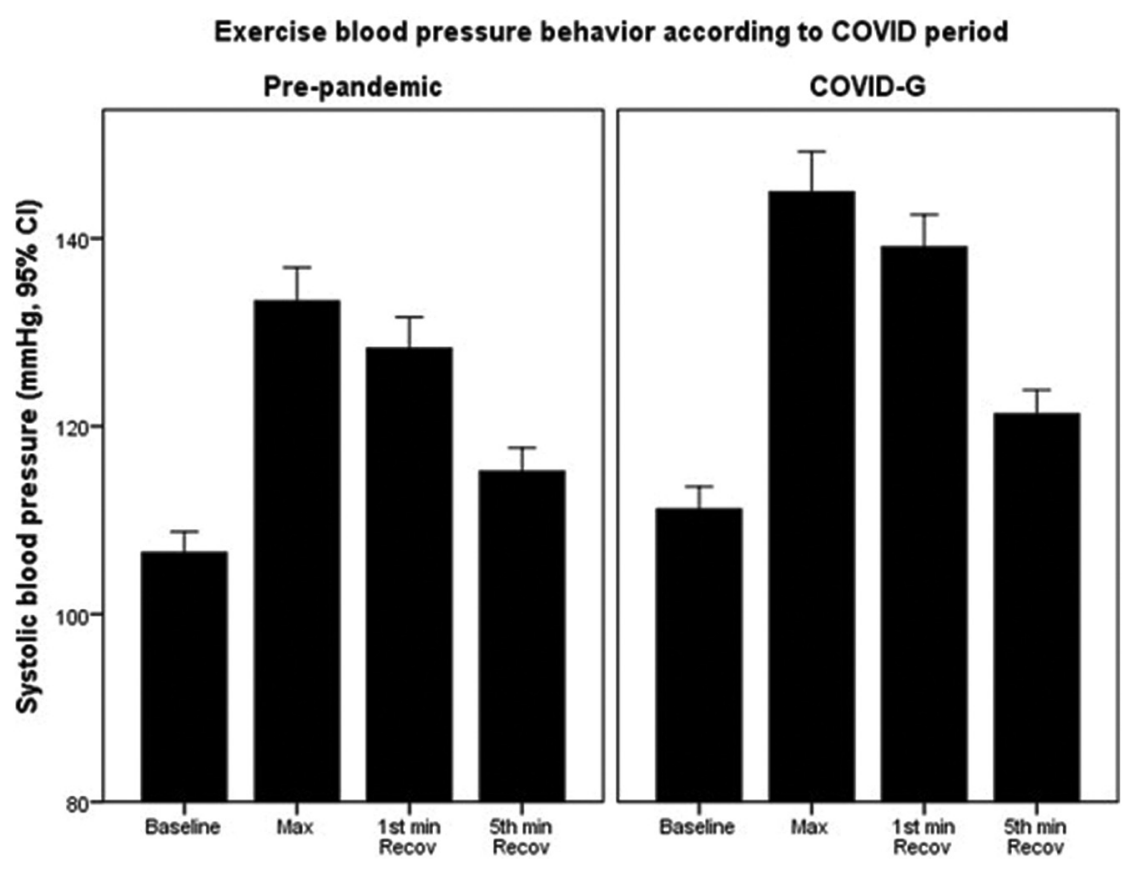

Figure 1. This graphic shows how systolic blood pressure levels are higher in patients that performed a cardiovascular exercise testing during the COVID pandemic.

\section{Discussion}

This study shows the ergometric performance of a group of patients who performed an exercise test in the COVID era with some peculiarities such as the use of face masks. The first finding was the lower number of ETs carried out during 2020, problem that has been widely published by various authors as an indirect consequence of the COVID-19 pandemic ${ }^{9-11}$.

In relation to the heart rate behavior, our findings show a habitual behavior of chronotropism, observations that agree with those found by Epstein et al. who performed maximal ET in a group of 16 healthy volunteers with and without face mask. These investigators found elevated levels of end-tidal carbon dioxide level when subjects wore a face mask ${ }^{12}$.

In patients who underwent exercise tests during the pandemic, blood pressure levels were higher than the group of patients who performed their exercise tests before the pandemic. One explanation for the systemic increases in blood pressure while patients exercised wearing a mask could be hypercapnia, which is associated with the rebreathing of carbon dioxide trapped within the mask and the concomitant increase in space physiological dead. This phenomenon has already been described in pathologies such as sleep apnea-hypopnea syndrome ${ }^{13}$. This observation does not accord with Epstein et al. that reported no significant changes in blood pressure at maximal effort. Another variable that could be associated with high blood pressure values is the increase in inspiratory and expiratory effort when breathing through a mask ${ }^{14}$.

\section{Limitations}

The study is not intended to present a historical cohort and cannot be a controlled clinical trial, but rather to describe the particularities of EPs performed during a single moment of the human race (PANDEMIC-G) and to refer to the usual findings observed before it (NO PANDEMIC). A major limitation is not having a randomized control group, but "real-world" circumstances and the restrictions of the pandemic did not make this possible. In the future, a controlled clinical trial may be required to describe the specific effect of wearing masks during an exercise test. Another limitation is the heterogeneity in the diagnoses of the patients, mainly because it is an emerging study and in the real world.

Conducting observations on patients during this time of restrictions, particularly the use of face masks, can establish research lines that in the future will expand 
knowledge in patients with respiratory diseases and obesity, even if the pandemic had already ended.

\section{Conclusions}

In the COVID period, a significantly lower number of exercise tests were performed. In addition, ET using face masks was associated with higher systolic blood pressure values and an increased number of tests suspended due to dyspnea. Maximum exercise tolerance did not show significant differences between both groups $(p=n s)$.

\section{Acknowledgments}

We thank all those who work in the Cardiac Rehabilitation and Physical Medicine Service at the National Institute of Cardiology who, with their daily work, largely made this work possible.

\section{Funding}

This research has not received any specific grant from agencies in the public, commercial, or non-profit sectors.

\section{Conflicts of interest}

None.

\section{Ethical disclosures}

Protection of human and animal subjects. The authors declare that no experiments were performed on humans or animals for this study.

Confidentiality of data. The authors declare that they have followed the protocols of their work center on the publication of patient data.
Right to privacy and informed consent. The authors have obtained the written informed consent of the patients or subjects mentioned in the article. The corresponding author is in possession of this document.

\section{References}

1. World Health Organization. WHO Coronavirus Disease (COVID-19) Dashboard. Geneva: World Health Organization; 2020. Available from: https://www.covid19.who.int. [Last accessed on 2002 Dec 30].

2. Noncommunicable Diseases; 2020. Available from: https://www.who.int/ data/gho/data/themes/noncommunicable-diseases. [Last accessed on 2002 Dec 30]

3. Khera A, Baum SJ, Gluckman TJ, Gulati M, Martin SS, Michos ED, et al. Continuity of care and outpatient management for patients with and at high risk for cardiovascular disease during the COVID-19 pandemic: a scientific statement from the American society for preventive cardiology. Am J Prev Cardiol. 2020;2020:100009.

4. Buonanno G, Stabile L, Morawska L. Estimation of airborne viral emission: quanta emission rate of SARS-CoV-2 for infection risk assessment. Environ Int. 2020;141:105794.

5. Lara J, Ilarraza-Lomelí H, García M, Bueno L. Utilidad pronóstica de la prueba de esfuerzo en la estratificación de riesgo de pacientes con insuficiencia cardiaca. Arch Cardiol Mex. 2015;85:201-6.

6. Venturelli M, Cè E, Paneroni M, Guazzi M, Lippi G, Paoli A, et al. Safety procedures for exercise testing in the scenario of COVID-19: a position statement of the Societa Italiana Scienze Motorie e Sportive. Sport Sci Health. 2020;2020:1-7.

7. Bhat R. Abstract 16698: cardiopulmonary exercise testing with an in-line filter during the COVID-19 pandemic. Circulation. 2020;142:A16698.

8. Hermes IL, Marianna GS, Jessica RC, Carlos BR, Rafael CD, Dolores RS, et al. Development and validation of a risk calculator predicting exercise-induced ventricular arrhythmia in patients with cardiovascular disease. Int J Cardiol. 2016;220:625-8.

9. Dawkes S. Supporting cardiac patients during the COVID-19 pandemic. Br J Cardiac Nurs. 2020;15:1-4.

10. Vigorito C, Faggiano P, Mureddu GF. COVID-19 pandemic: what consequences for cardiac rehabilitation? Monaldi Arch Chest Dis. 2020; 90:1315.

11. Faghy MA, Sylvester KP, Cooper BG, Hull JH. Cardiopulmonary exercise testing in the COVID-19 endemic phase. Br J Anaesth. 2020;125: 447-9.

12. Epstein D, Korytny A, Isenberg Y, Marcusohn E, Zukermann R, Bishop B, et al. Return to training in the COVID-19 era: the physiological effects of face masks during exercise. Scand J Med Sci Sport. 2021;31: 70-5.

13. Lévy P, Kohler M, McNicholas WT, Barbé F, McEvoy RD, Somers VK, et al. Obstructive sleep apnoea syndrome. Nat Rev Dis Primers. 2015;1:15015.

14. Lee HP, Wang DY. Objective assessment of increase in breathing resistance of N95 respirators on human subjects. Ann Occup Hyg. 2011;55:917-21. 